\title{
“Økumenisk Teologi” anno 2013
}

\author{
Ny lærebog af Peder Nørgaard-Højen \\ Post. doc. cand.theol. ph.d. \\ Jakob Egeris Thorsen
}

Peder Nørgaard-Højen, Økumenisk Teologi - En introduktion. København: Forlaget Anis 2013. 436 s. DKK 349.

\begin{abstract}
In the midst of what has been termed an "ecumenical winter" the publication of a new textbook in Danish on the topic of ecumenical theology is noteworthy. This article first and foremost gives a comprehensive introduction to Peder Nørgaard-Højen's Økumenisk Teologi - en introduktion ["Ecumenical Theology - an Introduction"]. In his book, Nørgaard-Højen prioritizes an analysis of the multilateral ecumenical dialogues in the Faith and Order-movement as well as the bilateral dialogues between the established confessional families. This article discusses the strengths and weaknesses of this approach in the light of the development of world Christianity anno 2013.
\end{abstract}

Key words: Peder Nørgaard-Højen - Ecumenism - ecumenical theology

- Faith and Order - global Christianity

Både i Danmark og internationalt er der i disse år langt mellem publikationer, der har den økumeniske teologi som emne og omdrejningspunkt. Modsat økumeniens storhedstid i 1960'erne, 70'erne og begyndelsen af 1980'erne, hvor de teologiske samtaler i og omkring Kirkernes Verdensråd (WCC) og Faith and Order førte til substantielle tilnærmelser mellem de gamle protestantiske kirkesamfund, den katolske kirke og de ortodokse, er det økumeniske engagement i de traditionelle råd og organisationer dalet. Desto glædeligere er det derfor, at en ny dansk grundbog med titlen Økumenisk Teologi - en introduktion af lektor emeritus Peder Nørgaard-Højen har set dagens lys og giver sit bud på en samlet fremstilling af den økumeniske teologis historie og problemstillinger. Økumenisk teologi og samarbejde er et bredt fænomen, og i bogen vælger Nørgaard-Højen især at beskæftige sig med de formelle økumeniske læresamtaler, sådan som de har fundet sted mellem de traditionelle kirkesamfund i anden halvdel af det 20. århundrede. Det er således den akademiske teologisk-dogmatiske dialog, der er i centrum, hvilket både er bogens styrke og svaghed. Denne artikel er en introduktion til og anmeldelse af bogen, der samtidig løbende og afslutningsvis vil diskutere forfatterens pointer og prioritering af stoffet $\mathrm{i}$ lyset af de kristendommens globale udbredelse og konfessionelle sammensætning anno 2013. 


\section{Det økumeniske udgangspunkt}

Bogens konstante udgangspunkt og drivkraft er en fastholdelse af forargelsen over, at Kristi kirke er splittet, og at denne splittelse ved menneskehånd ikke er en tilstand, som kristne bare må og skal slå sig til tåls med og resignere overfor. Nørgaard-Højen skriver således op imod de i dansk kirke og teologi udbredte positioner, at kirkens enhed enten stadigvæk fuldt og helt (om end usynligt) er givet i Kristus, eller at Han ved tidernes ende vil genoprette den. Det bekvemme resultat af hhv. den protologiske og eskatologiske enheds-argumentation er if. Nørgaard-Højen det samme, "[n]emlig at den kirkelige enhed aldrig [...] kan blive menneskets opgave” (263). En sådan påtaget ligegyldighed, der ofte oven i købet krydres med en letkøbt diffamering af det økumeniske anliggende, er ikke alene ødelæggende for den mellemkirkelige samtale, den fordyber også kløfterne og fordommene mellem konfessionerne og bidrager dermed aktivt til den fortsatte splittelse (ibid.). Heroverfor fastholder Nørgaard-Højen den kristne teologis forpligtelse til aktivt at prøve at overvinde de skel, som blev resultatet af tidligere generationers ofte nødvendige teologiske konfrontationer. Måden, det bedst foregår på, er den økumeniske dialog, som netop er en "dyb alvorlig samtale om sandheden" og ikke en kirkepolitisk forhandling, der blot "[t] ilstræber et kompromis på grundlag af en mindste fællesnævner" (258). Det kræver fra alle sider en villighed til at lade egne positioner efterprøve og til i sidste instans at ændre egne standpunkter, hvilket forståeligt nok kan være svært. Idealet er den kontinuerlige, åbne og sandhedssøgende dialog, der giver sig udslag $\mathrm{i}$ håndgribelige tilnærmelser når sand enighed opnås. Modstykket er både den ensidige kontroversteologiske afgrænsning og den moderne relativisme, der ikke tager de teologiske stridsspørgsmål alvorligt (293). En tredje vej, der kunne anerkende, at den samme kristne sandhed fandt forskellige udtryk, gives ikke for Nørgaard-Højen. Denne prioritering af den økumeniske teologiske læresamtale, og troen på, at det lader sig gøre sprogligt at formulere én fælleskirkelig sandhed, får ham til at udvise en vis skepsis overfor økumenisk engagement og praksis, der ikke til stadighed forsøger at løse de læremæssige uoverensstemmelser. Denne idealisme gør det imidlertid, som vi skal se nedenfor, også vanskeligt for NørgaardHøjen at anerkende faktiske aftaler og tilnærmelser som genuine, samt at se levende økumeniske udviklinger indenfor spiritualitet og gudstjeneste som reelle landvindinger. 


\section{Den økumeniske teologi og bevægelse}

Nørgaard-Højen belyser den økumeniske teologi fra fem forskellige vinkler (svarende til bogens kapitler). Først gives der er en basal indføring i emnet økumenisk teologi, en fremstilling af dens relevans i fortid og nutid, samt en beskrivelse af den økumeniske teologis plads i forhold til (og overlap med) de andre systematisk-teologiske discipliner. Ikke overraskende argumenter Nørgaard-Højen for, at teologien i dag nødvendigvis må være økumenisk orienteret. Vi lever mindre end nogensinde i geografisk afgrænsede mono-konfessionelle kulturer, men møder konstant de andre kristnes liv og lære. Hvis teologi er sandhedssøgen (og det er den for Nørgaard-Højen), kan man som kristen teolog ikke være "uinteresseret i det, der af medlemmer af andre kirkesamfund forstås som sandhed" (23). Om et sådant engagement så resulterer i en økumenisk åbenhed eller en kontroversteologisk afsondrethed er et spørgsmål om holdning, begge positioner er imidlertid et udtryk for den kirkesplittede realitet, og fungerer på sin vis som hinandens korrektiver. Kontroversteologien er økumeniens "kritiske samvittighed" (24), der sikrer at man bevarer jordforbindelsen, imens økumenien udfordrer fastlåste teologiske positioner og identiteter ved i det konkrete møde at vise, at den andens teologi kan være både komplementær og kompatibel.

Herefter følger en nøje historisk gennemgang af den økumeniske bevægelses opståen og udvikling i det 20. århundrede (kap 2). De fleste teologer kender til forvirringen over de mange økumeniske aktører (Faith and Order, Life and Work, missionsbevægelsen, WCC) og de utallige mere eller mindre vigtige og resultatrige møder og konferencer, der er blevet afholdt. Nørgaard-Højen opstiller bl.a. en oversigtlig flerfarvet tabel (116-117) og en grundig udredning de mange forskellige kommissioner og bevægelser i og omkring WCC og deres gensidige påvirkninger af udviklingen i den økumeniske bevægelse og den dermed forbundne teologis dagsorden. Når det er sagt, mangler der imidlertid noget. Alt det, der foregår udenfor den organiserede økumeni (og dens organisationer) får kun ganske få sætninger med på vejen. Således hører man i bogen næsten intet om, hvilken rolle den evangelikale Lausanne-bevægelse eller de pentekostale dele af kristenheden, hvoraf sidstnævnte jo i dag mindst udgør $25 \%$, har bidraget og vil kunne bidrage med til økumenisk teologi og praksis i verden i dag. ${ }^{1}$

1. D.B.Barrett, T.M. Johnson \& P.F.Crossing: "Missiometrics 2008: Reality Checks for Christian World Communions", Int. Bulletin of Missionary Research 32:1 (2008), 5 


\section{Konfessionelle profiler og visioner om enhed}

Før Nørgard-Højen tager fat på den økumeniske samtales hovedproblemer, præsenterer han, som i den klassiske konfessionskundskab, en karakteristik af de forskellige kirkesamfunds teologiske og kirkelige egenart og betydningen heraf for deres tilgang til den økumeniske dialog og de heraf følgende spørgsmål og visioner (kap 3). Særligt afsnittet om den katolske kirkes egenart og selvforståelse er præget af en afbalanceret grundighed, der skildrer "Romerkirkens" rykagtige forvandling fra økumenisk koldkriger til en engageret dialogpartner. Her demonstrerer Nørgaard-Højen et stort detailkendskab kendskab til katolske koncilsdokumenter og pavelige encyklikaer (124ff). Derudover viser forfatteren en nærmest antropologisk indsigt i den katolske trosverden og tænkemåde, der vidner om hans mangeårige deltagelse i den luthersk-katolske dialog. Nørgaard-Højens beskrivelser af hhv. anglikanismen, lutherdommen og de reformerte kirkers konfessionelle egenart og økumeniske profil er præcise, men unødvendigt korte, hvilket der imidlertid rådes bod på i en lang ekskurs i slutningen af kapitlet. Her præsenteres både Leuenberg-konkordien (153) og Porvoo-erklæringen (163) som eksempler på en hhv. luthersk-reformert og en luthersk-anglikansk økumenisk dialog og aftale, der giver forfatteren mulighed for at dykke helt ned i en præcis beskrivelse af de tre konfessioners ligheder og forskelle. Nørgaard-Højen fokuserer på det efter Porvoo-erklæringen i økumeniske kredse meget debatterede spørgsmål om det historiske bispeembedes nødvendighed: Er det et kendetegn sine qua non ved kirken eller er en bredere, traditionel protestantisk forståelse af "tilsyn" (episkopē) tilstrækkeligt, hvad enten dette tilsyn så knyttes til et embede eller en synode - således som i Leuenberg-konkordien? Ved at acceptere de lutherske kirker, hvor den historiske succession i bispeembedet er brudt (Danmark og Norge) som fuldt apostolske, synes den anglikanske kirke med Porvoo umiddelbart at have bevæget sig i.f.t. sin traditionelle position. Dette er if. Nørgaard-Højen imidlertid kun tilsyneladende. Samlæses Porvoo med samtidige anglikansk-reformerte erklæringer fra Tyskland og Frankrig (169), der ikke fører til fællesskab netop pga. det manglende bispeembede, bliver det klart, at anglikanerne står fast. Da Porvoo ydermere lægger op til, at den manglende historiske succession er en defekt, der i Danmark og Norge bør genoprettes, diskuterer Nørgaard-Højen spørgsmålet, hvorvidt Leuenberg og Porvoo, der begge er tiltrådt af folkekirken, er forenelige med hinanden. Det mener Nørgaard-Højen på baggrund af ovenstående ikke, at de er; Porvoo trækker teologisk i en højkirkelig-episkopal retning, som er dansk luthersk tradition fremmed. Her kunne man imidlertid spør- 
ge Nørgaard-Højen, om folkekirken er forpligtet til at læse Porvoo på den anglikanske kirkes præmisser, eller om den ikke med ligeså god ret kan forholde sig til teksten i sig selv og se den som en sund modpol til Leuenberg, der teologisk skaber det spændingsfelt mellem høj- og lavkirkelighed, i hvilket folkekirken som luthersk kirke jo på alle områder befinder sig: Mellem den katolske og anglikanske kirke på den ene side, og de mere radikalt reformatoriske evangeliske kirkesamfund på den anden side. Nørgaard-Højens beskæftigelse med Leuenberg/Porvoo åbenbarer en vis splittelse hos forfatteren, der på den ene side glædes over konkrete økumeniske resultater, samtidig med at han på den anden side kompromisløst fastholder bastante protestantiske positioner, der efterlader læseren med en trist tvivl om, hvorvidt det er ad den teologiske lærersamtales vej, at konkret økumenisk tilnærmelse i fremtiden konkret vil kunne ske.

\section{Økumeniske hovedproblemer og principspørgsmål}

De hovedproblemer, der har bestemt den økumeniske dialog i det 20. århundrede, har oftest deres rod i de dogmatiske spørgsmål, der i historiens løb har givet anledning til skismaer: Splittelsen mellem Øst og Vest i det 11. årh. og reformationen i det 16. årh. Adskillelsen i århundreder har i sig selv medført udviklingen af forskellige teologiske og kirkelige kulturer ("partikulæridentiter"), der ofte overtrumfer den kristne universalidentitet, også selvom de stridspørgsmål, der i sin tid medførte splittelsen, har mistet relevans. Dette er ifølge Nørgaard-Højen en af årsagerne til, at "[G]raden af receptionen af økumeniske indsigter er [så] chokerende ringe", og at “[M] an lukker [...] øjnene for diskrepansen mellem den vidtgående teologiske enighed og den faktisk endnu bestående kirkelige splittelse, der sjældent anfægtes alvorligt, men opretholdes på trods af enigheden og uden yderligere og dybereliggende motiver, hvorved man i vidt omfang risikerer at fremme den konfessionelle selvtilstrækkelighed" (181). Selvom der skinner en vis skuffelse igennem, er det Nørgaard-Højen meget om, at vi ikke forklejner de mange resultater, tilnærmelser og tværkonfessionelle venskaber, som det sidste halve århundredes økumeniske samtaler. Når der alligevel er skuffelse er det netop, fordi euforien, entusiasmen og spontaniteten var så stor i 1960'erne og 70'erne, og at resultaterne så blev af "en anden art, end man havde forventet"(180). Hvad de forskellige kirker forventede og forventer sig af den økumeniske dialog vender Nørgaard-Højen så tilbage til i bogen sidste kapitel. Af de andre hovedproblemer, som Nørgaard-Højen identi- 
ficerer og gennemgår, er forståelsen af apostolictet, filioque-striden, forholdet mellem skrift og tradition, retfærdiggørelse og ekklesiologi (med et afsnit om den luthersk-katolske "Fælleserklæring om Retfærdiggørelseslæren”), spørgsmål, der relaterer sig til dåb og nadver, og endelig embedsteologien, herunder naturligvis særligt spørgsmålet om bispe- og paveembede, hvoraf sidstnævnte behandles udførligt.

I den femte, sidste og længste del af sin fremstilling (105 sider!) behandles "Den økumeniske dialogs principspørgsmål”. Heri beskriver Nørgaard-Højen metodisk, hvordan den økumeniske samtale kan og bør føres, og forsøger således at formulere en økumenisk hermeneutik. Da valget af metode blandt andet altid vil være bestemt af det endemål, dvs. den vision om kirkelig enhed, som dialogpartnerne har, gives der også en oversigt og drøftelse af disse. Det andet afsnit (290) bestemmer og kvalificerer, hvordan den økumeniske samtale er en dialog om sandheden, imens det tredje (296) bestemmer dialogen som det fælleskristne arbejde med traditionen. Endelig behandler Nørgaard-Højen i det fjerde lange afsnit (369-399) alle de generelle hermeneutiske spørgsmål, der gør sig gældende i kirken og kirkerne, og som dermed har betydning for dialog generelt og for økumenisk dialog i særdeleshed. Dette fjerde og sidste afsnit i det femte kapitel truer med sine tretten underafsnit, fire under-underafsnit og ikke mindre end otte ekskurser med at udviske den røde tråd og forvirre den ikke meget skarpt opmærksomme læser. Når det er sagt, er det en guldgrube af hermeneutiske overvejelser.

\section{Økumenisk teologi anno 2013?}

Med "Økumenisk Teologi - en introduktion" får den teologiske læser et dybt indblik i det 20. århundredes økumeniske dialogs maskinrum. Man hører til gengæld ikke meget til de tilnærmelser og fælles udtryk, der er vokset frem i liturgi, bøn og spiritualitet. Én bog kan og skal ikke alt, men det valgte fokus gør, at bogen nærmere peger bagud end fremad. Læseren får ikke en manual til, endsige en forjættelse om, hvordan det økumeniske arbejde kunne tage form i det 21. århundrede, hvor de bilaterale samtaler ikke længere ligger øverst på dagsordenen. Dette medfører, at bogen unødvendigt ender i mol uden at vise frem mod de økumeniske muligheder, der faktisk åbner sig rundt omkring i den globaliserede kristne verden i disse år. Kristendommens globale udtryk anno 2013 er radikalt forandret i forhold til 1948, hvor WCC blev grundlagt. I dag bor der ligeså mange kristne i Afrika som i Europa, og flere kristne i det globale syd end 
i det gamle nordatlantiske kerneområde. ${ }^{2}$ Kun lidt over en fjerdel af de kristne tilhører i dag de gamle protestantiske og de ortodokse kirker, som i dag udgør hovedparten af WCC. De nye kristne i Afrika, Asien, Latinamerika og i de talrige migrantkirker i Vesten - evangikale, katolikker, pentekostale, "African Initiated" og uafhængige - er af forskellige årsager oftest ikke med. Det betyder imidlertid ikke, at al form for økumenisk engagement er dødt og kvalt i konservativ kristen vækst i syd. Nok er den form for økumeni, som bogen behandler, på retræte, men nye initiativer og netværk skyder frem. The Global Christian Forum er et sådant eksempel. ${ }^{3}$ Det er et barn af WCC, som klogelig er blevet sat fri og derved har opnået at samle kristne fra alle konfessioner. Efter en række regionale møder blev det første globale forum afholdt i Kenya i 2007 og det næste i Indonesien i 2011. Dette og andre tiltag burde have været nævnt. Sammen med Nørgaard-Højens lærebog vil jeg derfor $\mathrm{fx}$ tillade mig at anbefale Wesley GranbergMichaelsons From Times Square to Timbuktu - The Post-Christian West Meets the Non-Western Church ${ }^{4}$ som et nødvendigt supplement. Granberg-Michaelson er tidligere generalsekretær for den reformerte kirke i USA og mangeårigt engageret i WCC. Udover at beskrive de radikale forandringer og forskydninger i den globale kristendom, hvor det statistiske centrum i dag ligger i Timbuktu (Mali), forsøger han i bogen at analysere de økumeniske konsekvenser af denne udvikling og pege på de mange muligheder for økumenisk samarbejde og samtale (lokalt og globalt), der eksisterer anno 2013.

Til sidst et par praktiske bemærkninger: "Økumenisk Teologi" indeholder lange engelske og tyske citater, hvoraf sidstnævnte kan blive et problem $\mathrm{i}$ en undervisningssammenhæng, da tyskkundskaber beklageligvis ikke længere er et krav til de teologistuderende, og dette store teologiske sprog derfor de facto er ved at glide ud af pensum. Denne begrædelige udvikling må være Nørgaard-Højen bekendt, og man spørger derfor sig selv, hvorfor han fx oftest vælger at citere den officielle tyske oversættelse af koncilsdokumenter og pavelige encyklikaer, når der selvsagt også foreligger autoriserede engelske.

2. Alle de her nævnte tal stammer fra T.M Johnson \& K.R. Ross, Atlas of Global Christianity 1910-2010 (Edinburgh: Edinburgh University Press 2009).

3. Se: http://www.globalchristianforum.org/ (tilgået 22/10/2013)

4. Wesley Granberg-Michaelson, From Times Square to Timbuktu - The Post-Christian West Meets the Non-Western Church (Grand Rapids: William B. Eerdmans Publishing 2013). 